\title{
Corrosion behavior of low carbon steel processed by ECAP in neutral and alkaline environment
}

\author{
Jorgimara Oliveira Braga ${ }^{1}$ \\ Jefferson Fabricio Lins ${ }^{2}$ \\ Gabriel Pessoa de Castro ${ }^{2}$ \\ Helder Alves de Almeida Junior ${ }^{1}$ \\ Igor Cuzzuol dos Santos ${ }^{1 *}$ (1) \\ Gustavo Henrique Sousa ${ }^{1}$ \\ Izabel Lima Criscuolo \\ Cláudio Marcio Santana ${ }^{1}$ \\ Ursula Cid Pereira
}

\begin{abstract}
The purpose of this study was to evaluate the corrosion behavior of 1010 steel processed by Equal Channel Angular Pressing (ECAP), a technique that induces severe plastic deformation (SPD) in materials. The samples were processed by one and two passes of ECAP throught routes A and C. The corrosion behavior was evaluate using the potentiodynamic polarization and electrochemical impedance spectroscopy, using $\mathrm{NaCl}(\mathrm{pH}=6.5)$ and sodium hydroxide/sodium phosphate $(\mathrm{pH}=10.5)$ solutions. The polarization tests showed better performance for the samples processed by ECAP than in the as cast samples both in alkaline and neutral solutions. The results showed that alkaline solution presented higher corrosion rate for the as cast and one ECAP pass materials. It is seen that samples processed throught routes A and C develop a film stabilization on the surface of these samples. In addition, the values of polarization resistance obtained from the electrochemical impedance spectroscopy in $\mathrm{NaCl}$ environment were higher for sample processed in route $\mathrm{C}$.
\end{abstract}

Keywords: Low carbon steels; SPD; ECAP; Corrosion.

\section{Comportamento de corrosão de aço com baixo carbono processado por ECAP em ambiente neutro e alcalino}

\section{Resumo}

O objetivo deste estudo foi avaliar o comportamento à corrosão do aço 1010 processado por por Prensagem em Canais Equiangulares (ECAP), uma técnica que induz deformação plástica severa (DPS) em materiais. As amostras foram processadas em um e dois passes nas rotas $\mathrm{A}$ e $\mathrm{C}$. $\mathrm{O}$ comportamento em relação à corrosão foi estudado por meio da polarização potenciodinâmica e espectroscopia de impedância eletroquímica em soluções de $\mathrm{NaCl}(\mathrm{pH}=6,5)$ e hidróxido de sódio/fosfato de sódio $(\mathrm{pH}=10,5)$. Os testes de polarização apresentaram melhores desempenhos para as amostras processadas por ECAP do que nas amostras sem processamento, e isso ocorreu tanto na solução alcalina quanto na neutra. Os resultados mostram que os materiais no estado bruto de fusão e em apenas um passe de ECAP apresentaram maior taxa de corrosão em solução alcalina. Foi observado que as amostras processadas nas rotas A e C promoveram uma estabilização do filme em suas respectivas superfícies. Ademais, os valores de resistência de polarização obtidos por espectroscopia de impedância eletroquímica em ambiente de $\mathrm{NaCl}$ foram maiores para a amostra processada na rota $\mathrm{C}$.

Palavras-chave: Aços baixo carbono; DPS; ECAP; Corrosão.

\footnotetext{
${ }^{\prime}$ Departamento de Engenharia Metalúrgia e de Materiais, Universidade Federal de Minas Gerais - UFMG, Belo Horizonte, MG, Brasil. ${ }^{2}$ Departamento de Engenharia Metalúrgica, Universidade Federal Fluminense - UFF, Volta Redonda, RJ, Brasil.

*Corresponding author: igorcuzzuol@gmail.com
} cited. 


\section{Introduction}

Low carbon steels account for about $70 \%$ of the world's ferrous alloy production. These materials have been used in a range of industrial applications, from immense structural components to small parts of mechanical devices. In order to meet the market's demand, it is important to develop materials with special mechanical characteristics, such as high mechanical strength allied with high toughness. For example, some requirement mechanical properties of low carbon steels used for structural purposes are fatigue strength, wear resistance, mechanical strength associated with good toughness, weldability and corrosion resistance [1].

One of the methods applied to improve the mechanical properties of low carbon steels is the reduction of the material grain size using severe plastic deformation techniques. Severe plastic deformation (SPD) can be define as a group of techniques in which a high plastic deformation is apply in the material in order to produce ultrafine microstructures, also knows as ultrafine grains (UFG) [2]. Materials with UFG are of great interest, since the grain refinement promotes an increase in the material mechanical properties, enabling the production of components and structures that demand high mechanical resistance and high corrosion resistance [3].

ECAP was the SPD technique chosen in the present study. In this technique, the sample is place and press through an angular channel using a plunger. The nature of the imposed deformation is simple shear, which occurs as the sample passes through the die. The ECAP process is know as one of the most promising SPD techniques [4]. One characteristic of ECAP is the multiple-step, which means that various strain paths can be followed according to the processing routes defined by the billet rotation between successive passes. In route $\mathrm{A}$, the billet is not rotated between consecutive passes, whereas in route $\mathrm{C}$ the billet is rotated $180^{\circ}$ between passes. In one pass, the billet extend over only once through the channels [5].

The electrochemical behavior of materials with deformed grains is an important factor to be evaluate mainly in steels, because it has great applicability in industries, buildings and marine environments. However, it is observed that this kind of study has received limited attention and some results are incoherent [6]. Some studies [7,8] have showed that the basic electrochemical characteristics of ultra-fine grains do not vary significantly compared to their coarse grains. On the other hand, refined grain materials generally promote uniform corrosion rather than microscopic corrosion, which minimizes catastrophic results by localized corrosion attack on coarse grain materials.

Then, the purpose of this study is to obtain more information about corrosion behavior of low carbon steel processed by ECAP in different solutions, since there are many contraverses about the type of corrosion and electrochemical studies in steel that undergo severe plastic deformation (SPD).

\section{Methodology}

A commercial low carbon steel with nominal composition in Table 1 was used in the current study. The material was provided by Companhia Siderurgica Nacional (CSN-Volta Redonda/Brasil) in the form of as cast ingots. Billets having $10 \times 10 \times 50 \mathrm{~mm}$ were machined out from the as cast ingots

It is widely known that ECAP induces severe plastic deformation in metallic materials, which the processing consists of pressing the billet through two equal crosssection channels, intercepting at an angle $\Phi$. Since the billet does not change the cross section, the process can be repeated several times. The ECAP system of Federal Fluminense University (UFF) consists of an universal test machine (EMIC DL-60) with a maximum load capacity of $600 \mathrm{KN}$ and a die with two-part tool steel H13, dimensions of $10 \times 10 \mathrm{~mm}^{2}$ and channel angle of $90^{\circ}(\phi)$. The die and samples were lubricated with a calcium sulfonate grease prior to each assay. The samples were processed by one pass (no defined route) and two passes using routes A and $\mathrm{C}$ at room temperature.

The ECAP-processed samples were mechanically ground using abrasive papers to \#4000 $\mathrm{SiC}$ and polished using $1.0 \mu \mathrm{m}$ and $0.06 \mu \mathrm{m}$ silica colloidal suspension solution. The microstructural surface was examined by optical microscope (Leica DM ILM) coupled with Nikon Digital Sight camera and NIS element D.30 software. In addition, the microstructure was analyzed by the scanning electron microscope (SEM), model EVO MA10 from ZEISS with $\mathrm{LaB}_{6}$ filament. The SEM was operated by backscattered electron mode, acceleration voltage of $25 \mathrm{kV}$ and working distance (WD) of $8 \mathrm{~mm}$. After acquiring the image by optical microscope and SEM, the grain sizes were measured using the linear intercept method according to the standard ASTM E112 [9].

The electrochemical tests were carried out using potentiostat/galvanostat (SOLARTRON ANALYTICAL XM ECS/FRA) connected by three electrodes: 1010 steel as working electrode, $\mathrm{Ag} / \mathrm{AgCl}$ as reference electrode and platinum as counter electrode. The electrochemical tests consisted of immersing the electrodes in $100 \mathrm{ml}$ of the electrolyte in a glass cell. The solutions were prepared from analytical purity reagents (Sigma-Aldrich, 99.9\%) and distilled water. The-solutions used in the tests were $\mathrm{NaCl}\left(0.25\right.$ mol. $\left.\mathrm{L}^{-1}-\mathrm{pH} 6.5\right)$ and buffer solution of $\mathrm{Na}_{2} \mathrm{HPO}_{4}\left(0.1 \mathrm{~mol} . \mathrm{L}^{-1}-\mathrm{pH}\right.$ 10.5).

Table 1. Nominal chemical composition of the as cast SAE 1010 steel (in wt. \%)

\begin{tabular}{lcccccccc}
\hline Element & $\mathbf{C}$ & $\mathbf{M n}$ & $\mathbf{T i}$ & $\mathbf{A l}$ & $\mathbf{P}^{*}$ & $\mathbf{C u}^{*}$ & $\mathbf{M o}$ & $\mathbf{F e}$ \\
\hline $\begin{array}{l}\text { Composition } \\
\text { (wt } \%)\end{array}$ & 0.104 & 0.164 & 0.069 & 0.061 & 0.012 & 0.018 & 0.006 & remain \\
\hline *Impurites elements. & & & & & & &
\end{tabular}


The polarization curves were performed in order to evaluate a corrosion resistance of the deformed material compared to the as cast. The tests were conducted after potential stabilization and were performed in triplicates to achieve reproducibility in the results and in different solutions. The electrochemical impedance spectroscopy was realized to evaluate the corrosion bevavior in $0.25 \mathrm{NaCl}$ mol.L $\mathrm{L}^{-1}$ at immersion time of 48 hours using a frequency range of $10 \mathrm{kHz}$ to $10 \mathrm{mHz}$, signal amplitude of $10 \mathrm{mV}$ in relation to the open circuit potential (OCP) and scan rate of $5 \mathrm{mV} / \mathrm{s}$. The results obtained through the Electrochemical Impedance Spectroscopy (EIS) test were plotted on the Nyquist diagram, the representation is made by Z' and Z', which means real and imaginary part of the impedance, respectively. In other words, the abscissa is the real part (resistive terms, represented by $\mathrm{R}$ ) and the ordinate is the imaginary part (capacitive or inductive terms). In EIS tests, it is important to correlate the physical and chemical processes that occur in the system with electrical circuit elements to better understand the phenomena and interpretation of the results. The Zview ${ }^{\circledR}$ software was applied to data extrapolation and to obtain the equivalent circuit of the system.

In order to facilitate the understanding of the experimental procedure in the text, the as-cast sample was designated as A. The processed materials were labeled as B for one ECAP pass and $\mathrm{C}$ and $\mathrm{D}$ for two passes, using routes $\mathrm{C}$ and $\mathrm{A}$, respectively (shown in the Table 2).

\section{Results}

\subsection{Microstructural analysis}

After processing by ECAP, the material presented very elongated grains, as shown in Figure $1 \mathrm{~b}$. The grain size (Figure 1a) evaluated was about $48 \pm 2.7 \mu \mathrm{m}$ for the sample A and $23.9 \pm 3.1 \mu \mathrm{m}$ for sample B (Figure $1 \mathrm{~b}$ ). This mean a significant reduction of approximately $77 \%$ of the grain size after ECAP. The evaluated grain size for the samples C and D were $11.2 \pm 5.5 \mu \mathrm{m}$ and $8.6 \pm 7.8 \mu \mathrm{m}$, respectively. The high error values can be attributed to the heterogeneity induced by variation of grain size in the material, which makes the linear intercept method more difficult to be evaluate.

Table 2. Processed samples used in this study

\begin{tabular}{cc}
\hline Sample & Test Condition \\
\hline A & As cast \\
B & One pass \\
C & Two passes route C \\
D & Two passes route A \\
\hline
\end{tabular}
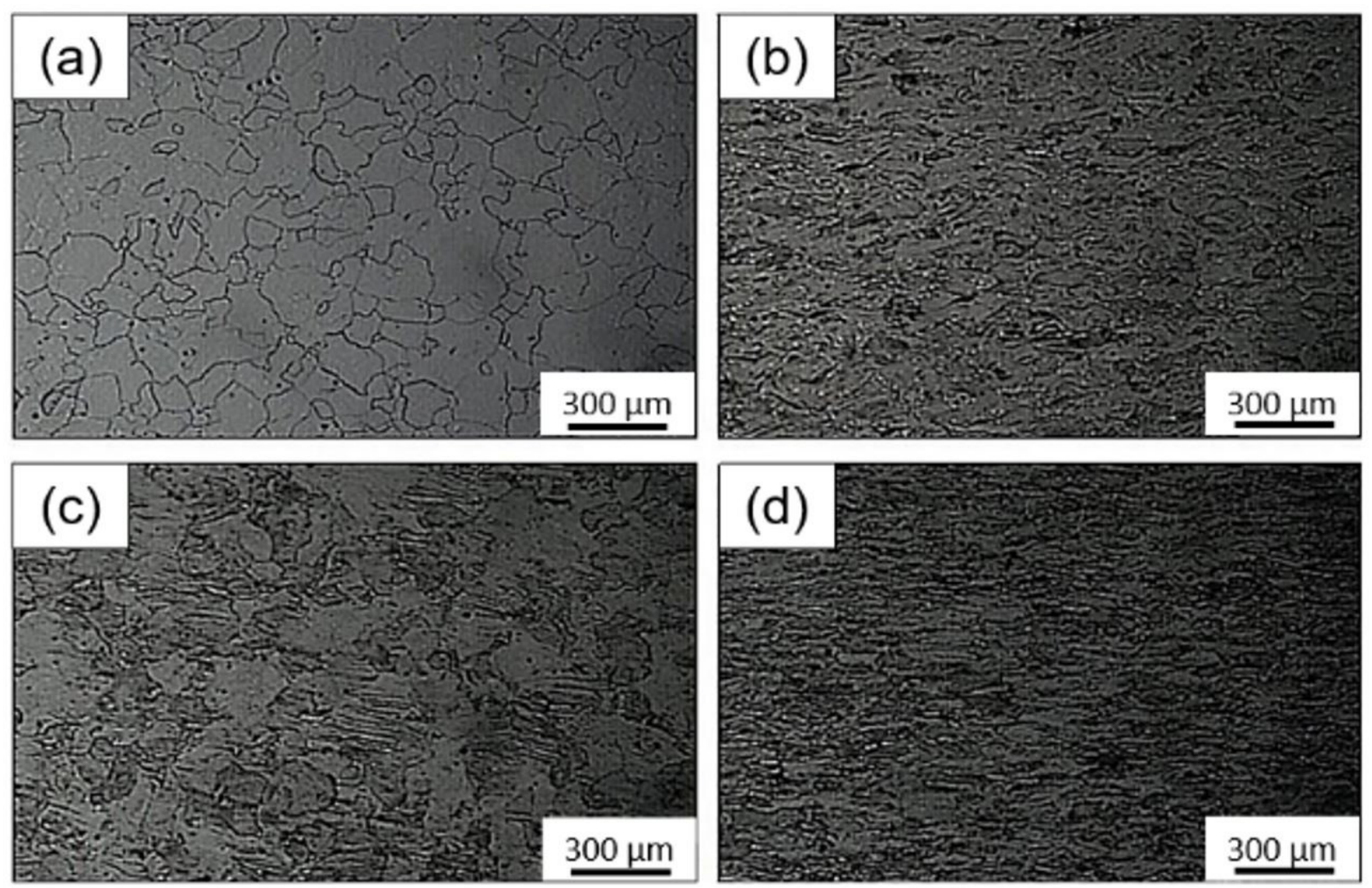

Figure 1. Optical Microscopy of 1010 steel in the cross section: (a) sample A; (b) sample B; (c) sample C and (d) sample D. 


\subsection{Electrochemical behavior in neutral and alkaline environment}

Figure 2a shows the electrochemical behavior of 1010 steel in $\mathrm{NaCl}$ solution (all results were obtained in triplicate). From these results, it is possible to observe an increase in the current density with a rise in the potential values. In Figure 2a, the increase in the current density begins at the pitting potential (Epitting) and the pitting corrosion occurs due to the rupture of the passive film. The potential values (Epitting) for the sample A was evaluated as $-0.43 \mathrm{~V}$ and the value for the processed materials was $-0.41 \mathrm{~V}$; $-0.34 \mathrm{~V}$; and $-0.36 \mathrm{~V}$ for samples $\mathrm{B}, \mathrm{C}$ and $\mathrm{D}$, respectively. These datas confirm a greater stability of the passivation film in the samples C and D.

The tests conducted in the alkaline solution with a sodium hydroxide $0.1 \mathrm{~mol} . \mathrm{L}^{-1} /$ sodium phosphate $0.1 \mathrm{~mol} . \mathrm{L}^{-1} \mathrm{pH}$ 10.5) are presented in Figure 2b. It is observed that the passive current density $\left(\mathrm{i}_{\text {pass }}\right.$ ) for the samples A and B are higher when compared to samples $\mathrm{C}$ and D. In other words, the material processed by two ECAP passes presented a passive film more stable when compared it to the as cast and the sample processed by only one pass.

Analysis from Figure 3 confirms a greater number of pits that occurred in the samples A and B (Figure 3a and 3b) in comparison with $\mathrm{C}$ and $\mathrm{D}$ :

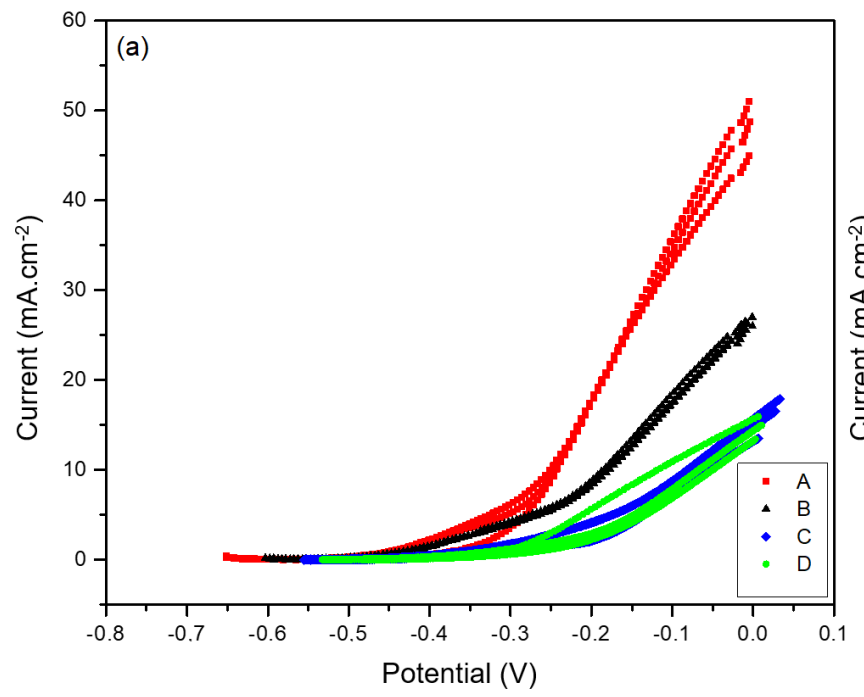

To confirm the behavior of the samples in $\mathrm{NaCl}$, measurements of electrochemical impedance were carried out after 48 hours immersion. Figure 4 and Table 3 present the equivalent circuit and fitting values, in wich the results were extrapolated by the Zview program. R1 is equivalent to the electrolyte resistance $(\mathrm{NaCl}), \mathrm{CPE} 1$ is a constant phase element and considered a non-ideal capacitor due to the heterogeneity of electrode surface and double layer characteristics. Polarization resistance was represented in the electrical circuit by R2.

Figure 5 shows the EIS results by Nyquist Plot representation, where the tests were conducted after 48 hours immersion in $\mathrm{NaCl}$ solution. The values of polarization resistance (R2) means that the larger the diameter of the semicircle the higher the resistance, and hence, the lower the corrosion rate. Therefore, the values obtained for polarization resistance were $\mathrm{R} 2=413.5 \Omega . \mathrm{cm}^{2}$ for the sample $\mathrm{A}$ and $964.6 \Omega . \mathrm{cm}^{2}, 1770 \Omega . \mathrm{cm}^{2}, 1322 \Omega . \mathrm{cm}^{2}$ for samples B, C and $\mathrm{D}$, respectively.

\section{Discussion}

After one ECAP pass (Figure 1b), it can be observed that the grains in the material became very elongated and presented a fragmented structure. In sample A, the perlite

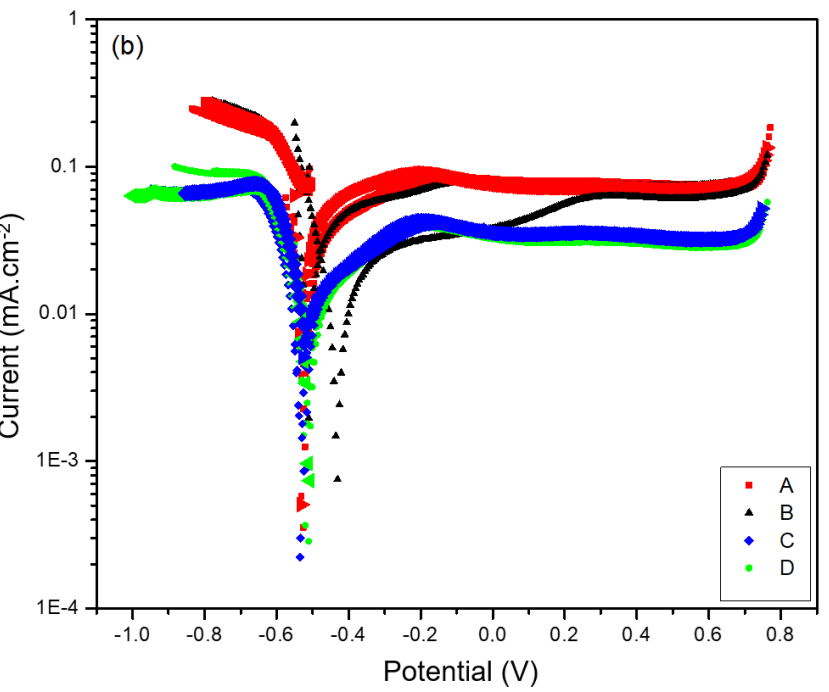

Figure 2. (a) Anodic polarization curve in $\mathrm{NaCl} 0.25$ mol. $\mathrm{L}^{-1}$; (b) anodic and cathodic polarization curve in $\mathrm{Na}_{2} \mathrm{HPO}_{4} 0.1 \mathrm{~mol}^{\mathrm{L}} \mathrm{L}^{-1}$.

Table 3. Simulation of the impedance data by the Zview program for immersion time 48 hours

\begin{tabular}{|c|c|c|c|c|c|c|}
\hline Samples & Immersion & $\mathbf{R}_{1}$ & $\frac{C P E_{1}-T}{\left(\mu \mathrm{Fm}^{-2}\right)}$ & $\frac{\mathrm{CPE}_{1-} \mathbf{P}}{\left(\mu \mathrm{Fm}^{-2}\right)}$ & $\frac{\mathbf{R}_{2}}{\left(\mathbf{O c m}^{2}\right)}$ & $\frac{\chi^{2}}{\left(10^{-3}\right)}$ \\
\hline & time (h) & & & & $\left(\Omega . \mathrm{cm}^{2}\right)$ & $\left(1^{-3}\right)$ \\
\hline $\mathbf{A}$ & 48 & 14.6 & 1154 & 0.75 & 413 & 0.94 \\
\hline B & 48 & 17.6 & 2185 & 0.78 & 964 & 1.76 \\
\hline C & 48 & 25.1 & 2284 & 0.84 & 1770 & 1.15 \\
\hline D & 48 & 19.4 & 2541 & 0.85 & 1322 & 6.54 \\
\hline
\end{tabular}



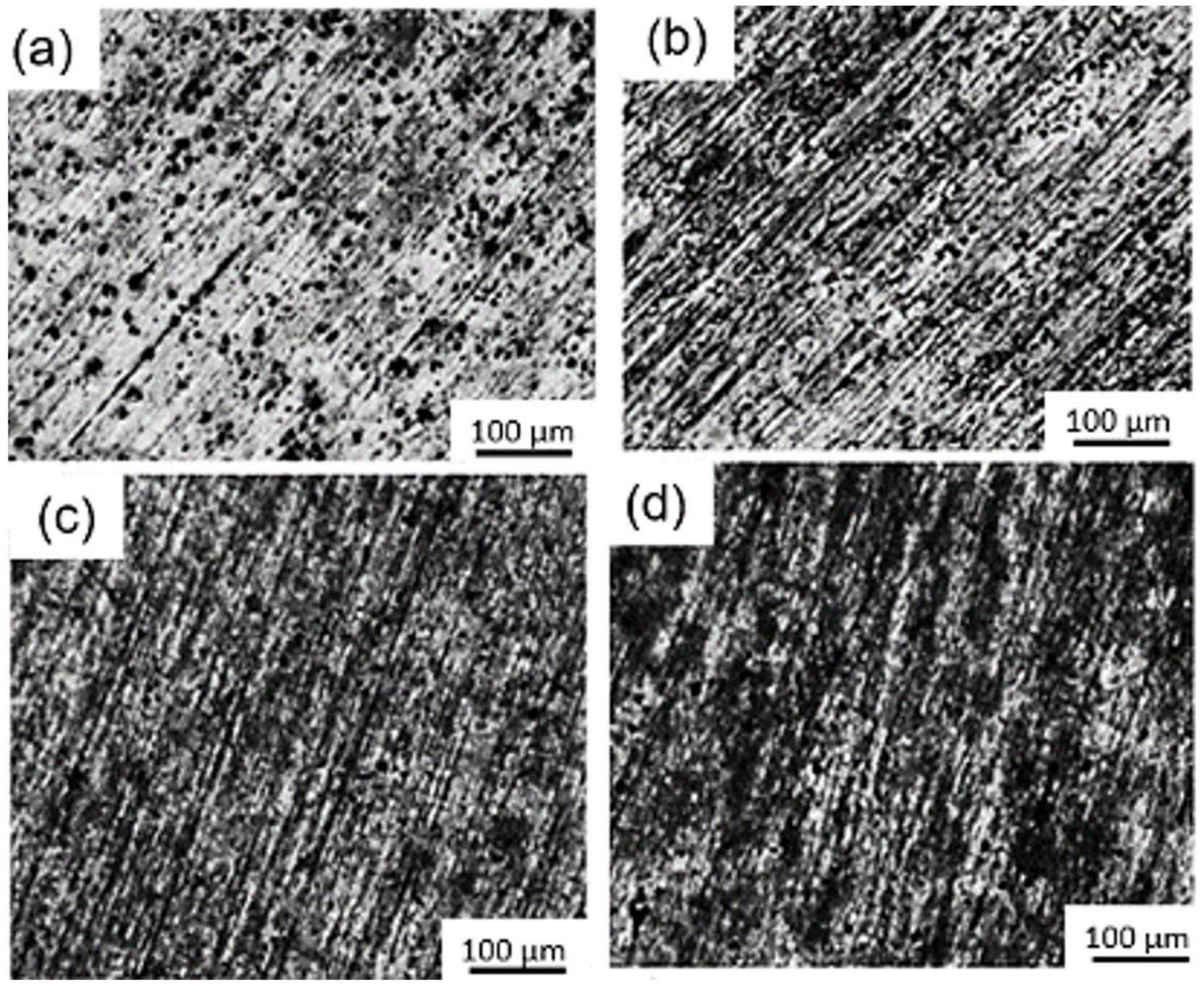

Figure 3. Optical microscopy after polarization test in $\mathrm{NaCl} 0.25$ mol.L

: (a) as cast; (b) one pass; (c) route $\mathrm{C}$ and (d) route $\mathrm{A}$.

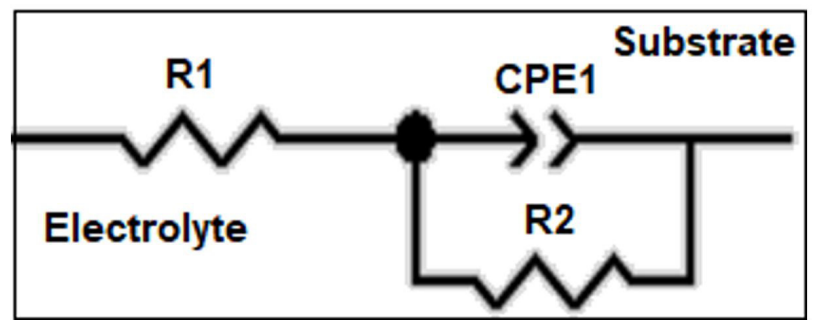

Figure 4. Equivalent circuit used to simulate the impedance.

has precipitated in the ferrite grain boundaries. After the first ECAP pass (sample B), it was noticed dark contours inside the ferrite grains. Probably, this is an indicative of the perlite phase fragmentation caused by intense deformation. For the sample $\mathrm{C}$ (Figure 1c), the morphology became equiaxed, which is a typical characteristic of this route. This phenomenum is possible due to a restoration of the cubicle element after rotation at $180^{\circ}$ [7]. As said earlier, the perlite contours were visible after the first ECAP pass. This observation agrees with Zrník et al. [10] and can be proved by the micrographs of low carbon steel in Figure 1c.

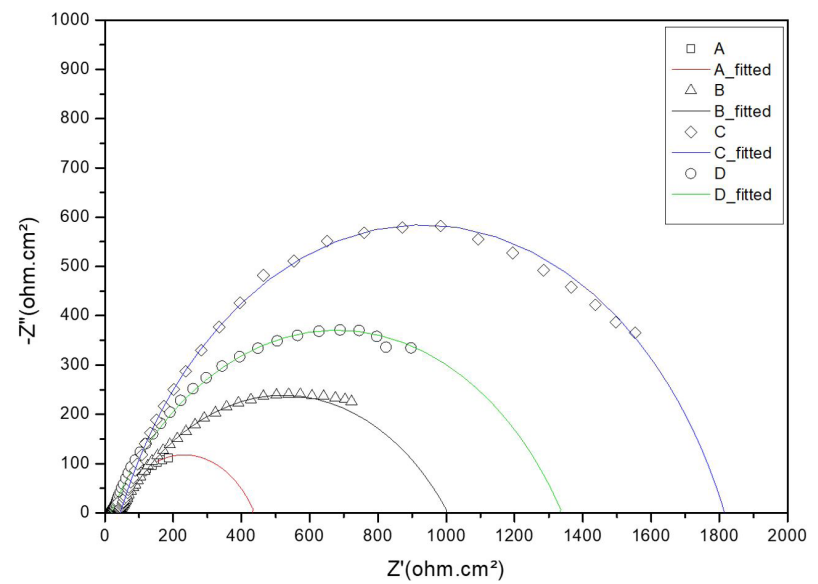

Figure 5. Nyquist diagram for 1010 steel in immersion for 48 hours in $\mathrm{NaCl}$ solution.

For the specimen D (Figure 1d), the grains have became extensively elongated with a very elongated ferritic and perlite structure. This is explained by a continuous and intense processing, which is favorable to a strong rolling texture formation [10]. In addition, it is seen a greater change 
Table 4. Summary of the main results obtained in this study

\begin{tabular}{cccccc}
\hline \multicolumn{7}{c}{ Corrosion results } \\
\hline Sample & Test condition & Grain size $(\boldsymbol{\mu m})$ & Epitting $(\mathbf{V})$ & ipass $\left(\mathbf{m A . c m} \mathbf{-}^{\mathbf{2}}\right)$ & $\mathbf{R}_{\mathbf{2}}\left(\mathbf{\Omega} . \mathbf{c m}^{2}\right)$ \\
\hline A & As cast & $48 \pm 2.7$ & -0.43 & 0.08 & 413.5 \\
B & One pass & $23 \pm 3.1$ & -0.41 & 0.07 & 964.6 \\
C & Two passes route C & $11.2 \pm 5.5$ & -0.34 & 0.03 & 1770 \\
D & Two passes route A & $8.5 \pm 7.8$ & -0.36 & 0.04 & 1322 \\
\hline
\end{tabular}

in the microstructure of the material processed by route A rather than $\mathrm{C}$. This is explained by the fact that route A developed grain substructures. Elongated and small grains were also detected in route $\mathrm{A}$ while a more homogeneous microstructure with equiaxed grains are noticed in route $\mathrm{C}$.

According to the diagram of $\mathrm{Fe}-\mathrm{H}_{2} \mathrm{O}$ (diagram of Pourbaix- E-pH), it is concluded that the iron is passivated by $\mathrm{Fe}(\mathrm{OH})_{3}$ for a pH of 6.5 [11]. As shown before (Figure 2a), the increase in the current density begins at the pitting potential (Epitting) and pitting corrosion occurs due to the rupture of the passive film. The formation of pitting in a carbon steel have been studied by Eletre et al. [11] in $\mathrm{NaCl}$ solution and the authors have proved that chloride ion leads to a sudden and noticeable increase in the current density, which promotes a destruction of the passive film and, consequently, a beginning of the corrosion by pitting. The same analysis was reported by $\mathrm{Bi}$ et al. [12]. In this work, the passive film was destroyed, and the 1010 steel surface was exposed to an active dissolution point. From Figure 2a, it is observed that the samples A and B have larger currents with a increasing in the potential, especially above $-0.35 \mathrm{~V}$. This means that the specimens $\mathrm{C}$ and $\mathrm{D}$ presents greater resistance to pitting comparing to the samples A and B.

Previous study by Hadzima et al. [8] evaluated the corrosion resistance of an IF steel processed by two passes of ECAP via route $\mathrm{C}$ in $\mathrm{NaCl}$ solution. This work confirmed that the Epitting increased from $+70 \mathrm{mV}$ for the as cast up to $+250 \mathrm{mV}$ for the deformed material. The authors confirmed an increase in the Epitting values between the imperfect passivity grain boundaries and the pitting region. This supports the observation that passive film is more stable for the materials with elongated grains than for those with coarse grains. As seen in Figure 2b, samples C and D have formed a passive film more stable when compared to $\mathrm{A}$ and B. Once again, this can be explained by the stability of the film, which is more stable for the deformed samples, due to the high surface energy created after ECAP processing.

It has been proved that in the alkaline environment the film basically corresponds to a double layer model, consisting of magnetite in the inner region and a ferric oxide in an external region, according to the $\mathrm{Fe}_{3} \mathrm{O}_{4} / \mathrm{Fe}_{3}{ }^{+}$structure [13]. Using the polarization curve showed in Figure $2 b$ it was possible to obtain $\mathrm{i}_{\text {pass }}$ values. The values for the specimens $A$ and B were measured at $0.08 \mathrm{~mA} . \mathrm{cm}^{-2}$ and $0.07 \mathrm{~mA} . \mathrm{cm}^{-2}$. For $\mathrm{C}$ and $\mathrm{D}$ the values were $0.03 \mathrm{~mA} . \mathrm{cm}^{-2}$ and $0.04 \mathrm{~mA} . \mathrm{cm}^{-2}$, respectively. The passivation of steel in the alkaline solution is due to the formation of a very thin, but highly protective oxide/hydroxide layer [14].

Some authors found EIS values different from this study $[15,16]$. This might occur due the fact that the initial conditions were different, despite the same equivalent circuit for data simulation were used. In summary, samples with higher deformation $(\mathrm{C}$ and $\mathrm{D})$ presented better performance than the less deformed ones (A and B), as proved in the Nyquist plots (Figure 5). These are also in agreement with the results obtained by the polarization technique, as shown in the Figure 2. The summary of the main results, such as grain size and electrochemicals values are shown in Table 4.

\section{Conclusion}

From the results obtained in this work, it was possible to evaluate the corrosion behavior of the samples before and after the deformation in different environments. It can therefore be concluded that:

- Sample A presented very coarse grains compared to the samples processed by ECAP. Large elongation grains and fragmented structures was observed in the deformed samples;

- Higher values of Epitting were found for the deformed samples in $\mathrm{C}$ and $\mathrm{D}$ using $\mathrm{NaCl}$ solution ( $\mathrm{pH}$ 6.5). Futhermore, higher current densities with the increase potential was found for the specimens A and B;

- It was observed a greater value of polarization resistance (immersion time of 48 hours), for the material processed by routes A and C using ECAP. This means a presence of a better resistance to the localized corrosion;

- In the alkaline sodium hydroxide/sodium phosphate $\mathrm{pH} 10.5$ environment, the formed passive film is more stable for higher deformed samples - C and D (lower passivation current $\left.-\mathrm{i}_{\text {pass }}\right)$.

\section{Acknowledgements}

The authors would like to thank CAPES (Coordenação de Aperfeiçoamento de Pessoal Ensino Superior) for their financial support. 


\section{References}

1 Abdalla AJ, Hashimoto TM, Pereira MS, Anazawa RM. Formação da fase bainítica em aços de baixo carbono. Revista Brasileira de Aplicações de Vácuo. 2008;25(3):175-181.

2 Kawasaki M, Langdon TG. Producing ultrafine-grained materials through severe plastic deformation. Emerging Materials Research. 2014;3(6):252-260.

3 Azushima A, Kopp R, Korhonen A, Yang DY, Micari F, Lahoti GD, et al. Severe plastic deformation (SPD) processes for metals. CIRP Annals. 2008;57(2):716-735.

4 Valiev RZ, Langdon TG. Principles of equal-channel angular pressing as a processing tool for grain refinement. Progress in Materials Science. 2006;51(7):881-981.

5 Figueiredo RB, Pinheiro IP, Aguilar MTP, Modenesi PJ, Cetlin PR. The finite element analysis of equal channel angular pressing (ECAP) considering the strain path dependence of the work hardening of metals. Journal of Materials Processing Technology. 2006;180(3):30-36.

6 Dobatkin S, Zrnik J, Mamuzic I. Ultrafine-grained low carbon steels by severe plastic deformation. Metalurgija. 2008;47(3):181-186.

7 Shin DH, Kim BC, Kim YS, Park KT. Microstructural evolution in a commercial low carbon steel by equal channel angular pressing. Acta Materialia. 2000;48(9):2247-2255.

8 Hadzima B, Janeček M, Estrin Y, Kim HS. Microstructure and corrosion properties of ultrafine-grained interstitial free steel. Materials Science and Engineering A. 2007;462(1-2):243-247.

9 American Society for Testing and Materials. ASTM E112-13: standard test methods for determining average grain size. West Conshohocken: ASTM International; 2015.

10 Zrník J, Mamuzić I, Dobatkin SV, Stejskal Z, Kraus L. Low carbon steel processed by equal channel angular warm pressing. Metalurgija. 2007;46(1):21-27.

11 Eletre AE, Abdallah M, Soliman MG, Mabrouk EM. Inhibition of pitting corrosion C-steel in NaCl solution by some inorganic compounds. Commun. Fac. Sci. Univ. Ank. Ser. B. 2000;46:25-31.

12 Bi H, Li Z, Liu J, Cheng Y, Toku-Gyamerah I. Study on pitting corrosion of storage tank bottom steel in acidic condition using acoustic emission. International Journal of Electrochemical Science. 2015;10:4416-4427.

13 Nagajama MI, Cohen M. The anodic oxidation of iron in a neutral solution. Journal of the Electrochemical Society. 1962;109(9):781-795.

14 Yang Y, Xiao L, Zhao Y, Wang F. Hydrothermal synthesis and electrochemical characterization of a-MnO2 nanorods as cathode material for lithium batteries. International Journal of Electrochemical Science. 2008;3(1):67-74.

$15 \mathrm{Hu}$, Cao SA, Xie J. EIS study on the corrosion behavior of rusted carbon steel in 3\% NaCl solution. AntiCorrosion Methods and Materials. 2013;60(2):100-105.

16 Nady H, El-Rabiei MM, Samy M. Corrosion behavior and electrochemical properties of carbon steel, commercial pure titanium, copper and copper-aluminum-nickel alloy in 3.5\% sodium chloride containing sulfide ions. Egyptian Journal of Petroleum. 2017;26(1):79-94.

Received: 11 Apr. 2020

Accepted: 19 Oct. 2020 